\title{
Antiproliferative effect of exemestane in lung cancer cells
} Angelos Koutras*1, Efstathia Giannopoulou ${ }^{2}$, Ismini Kritikou ${ }^{2}$, \author{
Anna Antonacopoulou ${ }^{2}$, TR Jeffry Evans ${ }^{3}$, Athanasios G Papavassiliou ${ }^{4}$ and \\ Haralabos Kalofonos ${ }^{1}$
}

Address: ${ }^{1}$ Division of Oncology, Department of Medicine, University Hospital of Patras, Rion 26504, Greece, ${ }^{2}$ Clinical Oncology Laboratory, University Hospital of Patras, Patras Medical School, Rion 26504, Greece, ${ }^{3}$ University of Glasgow, Cancer Research UK Beatson Laboratories, Garscube Estate, Switchback Road, Glasgow G61 1BD, UK and ${ }^{4}$ Department of Biological Chemistry, Medical School, University of Athens, 11527 Athens, Greece

Email: Angelos Koutras* - angkoutr@otenet.gr; Efstathia Giannopoulou - giannop@upatras.gr; Ismini Kritikou - niniquear@yahoo.com; Anna Antonacopoulou - antonac@gmail.com; TR Jeffry Evans - j.evans@beatson.gla.ac.uk; Athanasios G Papavassiliou - papavas@med.uoa.gr; Haralabos Kalofonos - kalofon@med.upatras.gr

* Corresponding author

Published: 24 November 2009

Molecular Cancer 2009, 8:109 doi:10.1186/1476-4598-8-109
Received: 13 June 2009

Accepted: 24 November 2009

This article is available from: http://www.molecular-cancer.com/content/8/I/109

(c) 2009 Koutras et al; licensee BioMed Central Ltd.

This is an Open Access article distributed under the terms of the Creative Commons Attribution License (http://creativecommons.org/licenses/by/2.0), which permits unrestricted use, distribution, and reproduction in any medium, provided the original work is properly cited.

\begin{abstract}
Background: Recent evidence suggests that estrogen signaling may be involved in the pathogenesis of non-small cell lung cancer (NSCLC). Aromatase is an enzyme complex that catalyses the final step in estrogen synthesis and is present in several tissues, including the lung. In the current study we investigated the activity of the aromatase inhibitor exemestane in human NSCLC cell lines $\mathrm{H} 23$ and A549.
\end{abstract}

Results: Aromatase expression was detected in both cell lines. $\mathrm{H} 23$ cells showed lower protein and mRNA levels of aromatase, compared to A549 cells. Exemestane decreased cell proliferation and increased apoptosis in both cell lines, $48 \mathrm{~h}$ after its application, with A549 exhibiting higher sensitivity than $\mathrm{H} 23$ cells. Aromatase protein and mRNA levels were not affected by exemestane in A549 cells, whereas an increase in both protein and mRNA levels was observed in $\mathrm{H} 23$ cells, 48 $\mathrm{h}$ after exemestane application. Moreover, an increase in cAMP levels was found in both cell lines, $15 \mathrm{~min}$ after the administration of exemestane. In addition, we studied the effect of exemestane on epidermal growth factor receptor (EGFR) localization and activation. Exemestane increased EGFR activation 15 min after its application in $\mathrm{H} 23$ cells. Furthermore, we demonstrated a translocation of EGFR from cell membrane, $24 \mathrm{~h}$ after the addition of exemestane in $\mathrm{H} 23$ cells. No changes in EGFR activation or localization were observed in A549 cells.

Conclusion: Our findings suggest an antiproliferative effect of exemestane on NSCLC cell lines. Exemestane may be more effective in cells with higher aromatase levels. Further studies are needed to assess the activity of exemestane in NSCLC.

\section{Background}

Lung cancer is the most common cause of cancer mortality for both men and women in the United States and non-small cell lung cancer (NSCLC) accounts for $80 \%$ of all cases. The etiology of NSCLC has not yet been efficiently elucidated. Recent evidence suggests that estrogen 
signaling is critical for the progression of malignancies that express estrogen receptors (ER) and may also be involved in the pathogenesis of NSCLC [1-7]. In a recent review, Dubey et al [8] suggest that a number of principles related to the pathogenesis or even the management of the disease, may apply to both breast and lung carcinoma.

Despite previous conflicting data, recent studies have indicated that estrogen receptors alpha (ER $\alpha)$ and beta (ER $\beta$ ) are overexpressed in certain proportions of malignant lung cells $[3,5-7,9]$. Moreover, stimulation of cell proliferation with estrogens has been reported in lung cancer tissue cultures, further supporting the potential biologic role of ERs in lung carcinogenesis [3-6]. A difference of ER expression between men and women has been reported in lung cancer by Fasco et al, who found higher levels of ER in female patients [10]. In addition, women with lung cancer have also higher levels of estrogens compared to healthy females of the same age [11]. It has been hypothesized that estrogens may interact with carcinogenic components of tobacco, affecting the risk for lung cancer development. A positive association between exogenous and endogenous exposure to estrogens and the development of lung adenocarcinoma has been described in women [1], even though other studies have failed to show such a correlation [12]. Furthermore, hormone replacement therapy has been associated with shorter survival in lung cancer patients $[11,13]$. Recent data have also provided evidence for an association between estrogen levels and outcome, and this correlation may possibly contribute to the survival advantage seen in older women with NSCLC [14].

Given the accumulating data relating to the significance of hormonal pathways in NSCLC, a role for antiestrogen treatments in the management of the disease should not be excluded. Although tamoxifen has been evaluated in combination with chemotherapy in patients with NSCLC $[15,16]$, the agonistic activity of this agent on the ER might limit its usefulness in lung cancer $[3,4,11]$. Moreover, clinical studies using tamoxifen in breast cancer patients have not shown a reduction in lung cancer incidence [17]. Fulvestrant is a pure antiestrogen which has shown antiproliferative activity in estrogen-induced growth of lung cancer cells $[3,5]$. In view of a possible functional interaction between the ER and the epidermal growth factor receptor (EGFR) pathways in NSCLC, fulvestrant has also been evaluated in combination with EGFR tyrosine-kinase inhibitors (TKIs), both in NSCLC xenografts $[4,9]$ and in women with NSCLC [18], with promising results. Similar studies evaluating the combination of fulvestrant with other TKIs are under way.

Assuming that lung cancer is responsive to hormonal manipulations, another modality to alter estrogen signal- ing could be via estrogen synthesis inhibition. Aromatase is a cytochrome P450 enzyme complex that mediates the final, rate-limiting step in estrogen synthesis. More specifically, aromatase catalyzes three consecutive hydroxylation reactions converting $\mathrm{C} 19$ androgens to aromatic C18 estrogens. Upon receiving electrons from NADPH-cytochrome P450 reductase, aromatase converts androstenedione and testosterone to estrone and estradiol, respectively [19]. Apart from its expression in the ovaries, the enzyme is also present in other tissues such as breast, lung, liver and brain. Aromatase expression has been recently demonstrated in NSCLC tumour specimens $[5,7]$, which could represent a local source of estrogen production in lung cancer tissue in both genders.

Aromatase inhibitors (AIs) might also be effective in NSCLC by reducing the biosynthesis of estrogens and thereby inhibiting estrogen-depended pathways in lung tumours. Currently, there are two classes of third-generation aromatase inhibitors: reversible nonsteroidal inhibitors, such as anastrozole and letrozole, and irreversible steroidal inactivators, such as exemestane. Exemestane inhibits aromatization in vivo by about 98 percent in postmenopausal breast cancer patients. In the adjuvant setting, switching to exemestane after 2-3 years of adjuvant tamoxifen was more effective than continuing tamoxifen [20]. In this trial, patients assigned to exemestane displayed a trend of lower incidence of subsequent primary lung cancer compared to those maintained on tamoxifen (4 vs 12).

In the current study, we investigated the anti-tumour activity of exemestane in lung cancer cell lines $\mathrm{H} 23$ and A549 on cell proliferation and apoptosis. In addition, we examined the effect of exemestane on aromatase activity and expression levels. We also tested the hypothesis that exemestane might exert its effect on aromatase activity through a cAMP-dependent mechanism. Finally, we evaluated the effect of exemestane on EGFR localization and activation.

\section{Results}

In vitro experiments were performed in two NSCLC cell lines, H23 and A549. Both cell lines express ER $\alpha$ and ER $\beta$ $[3,5,7]$. H23 cells express higher levels of ER $\alpha$ compared to A549 cells, whereas the latter cell line expresses higher levels of ER $\beta$ compared to H23 cells [7].

\section{Aromatase expression in $\mathrm{H} 23$ and $\mathrm{A549}$ cells}

A549 cells express higher protein and mRNA aromatase levels than $\mathrm{H} 23$ cells (Fig. 1 and Fig. 2). Aromatase activity was detected in both cell lines. Exemestane did not affect protein nor mRNA levels of aromatase in A549 cells, $48 \mathrm{~h}$ after its application. In contrast, protein and mRNA levels 


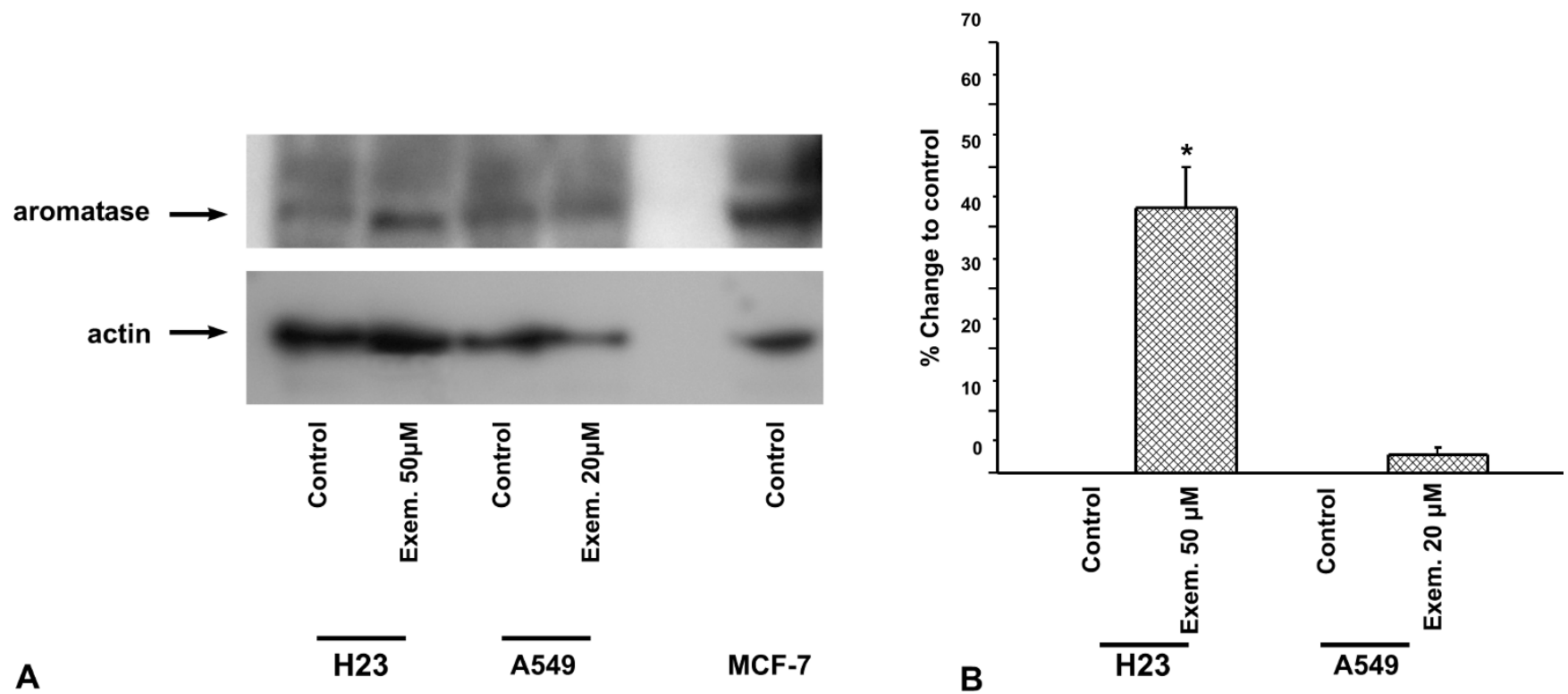

\section{Figure I}

The effect of exemestane on protein levels of aromatase in $\mathbf{H 2 3}$ and A549 cells. A: H23 and A549 cells were treated with $50 \mu \mathrm{M}$ and $20 \mu \mathrm{M}$ exemestane respectively and $48 \mathrm{~h}$ later, cells were lysed and analyzed in SDS-PAGE. Actin was used as an internal control. The figure is a representative from at least three independent experiments. B: Quantification of western blot images. The results are expressed as \% change of control. Asterisks denote a statistically significant difference (unpaired $t$-test) compared to control. * $P<0.05$.

were increased in $\mathrm{H} 23$ cells, $48 \mathrm{~h}$ after its application (Fig. 1 and Fig. 2).

\section{Exemestane inhibited $\mathrm{H} 23$ and $\mathrm{A549}$ cell growth and increased apoptosis}

We studied the effect of exemestane on the proliferation of the human NSCLC cell lines, H23 and A549. Exemestane inhibited cell proliferation in both cell lines in a dose dependent manner, $48 \mathrm{~h}$ after its application (Fig. 3a). Fifty percent growth inhibition was recorded at $50 \mu \mathrm{M}$ for $\mathrm{H} 23$ and $20 \mu \mathrm{M}$ for A549. All further experiments for each cell line were performed with these concentrations of exemestane. Moreover, evaluating the effect of testosterone on proliferation of $\mathrm{H} 23$ and A549 cells, we found that testosterone did not affect cell proliferation at lower doses whereas it decreased cell number at higher doses (Fig. 3b).

Furthermore, the percentage of annexin ${ }^{+}$cells increased 48 $\mathrm{h}$ after treatment of $\mathrm{H} 23$ or A549 with exemestane compared to untreated cells (Fig. 4). Although there are data regarding cell cycle arrest by aromatase inhibitors in breast cancer cells [21], a similar effect was not found with exemestane in NSCLC cell lines in our study (data not shown).

\section{Aromatase activity in $\mathbf{H 2 3}$ and $\mathbf{A 5 4 9}$ cells}

As aromatase catalyses the conversion of androstenedione and testosterone to estrone and estradiol, respectively, its activity was determined by the production of estradiol after treatment of cells with exemestane. H23 and A549 cells were treated with exemestane without exogenous addition of testosterone at the indicated concentrations, and $15 \mathrm{~min}$ later estradiol production was measured. Previous reports have indicated that the estimated time for achieving $50 \%$ of aromatase inhibition by exemestane is $13.9 \mathrm{~min}[19,22]$. We found that a 15 min treatment with exemestane caused a non-significant reduction of estradiol levels in both cell lines (Fig. 5a). However, estradiol levels were increased 6, 8, 12, 24 and $48 \mathrm{~h}$ later in both cell lines (Fig. 5a).

Furthermore, aromatase activity was determined at 6, 8, 12 and $24 \mathrm{~h}$, following treatment of both cell lines with 1 $\mu \mathrm{M}$ testosterone. This experiment was used as an internal control. The time point of $15 \mathrm{~min}$ was not used since there are previous data showing that in breast cancer cells, aromatase is activated $6 \mathrm{~h}$ after incubation with a suitable substrate [23]. As was expected, we found that application of testosterone increased the levels of estradiol (Fig. 5b), with the maximum production of estradiol being observed $12 \mathrm{~h}$ after treatment of cells with the substrate.

\section{cAMP levels in $\mathrm{H} 23$ and A549 cells}

Evaluating the effect of exemestane on cAMP levels, we found an increase of cAMP levels in both cell lines, $15 \mathrm{~min}$ after treatment of cells with exemestane. This effect was 


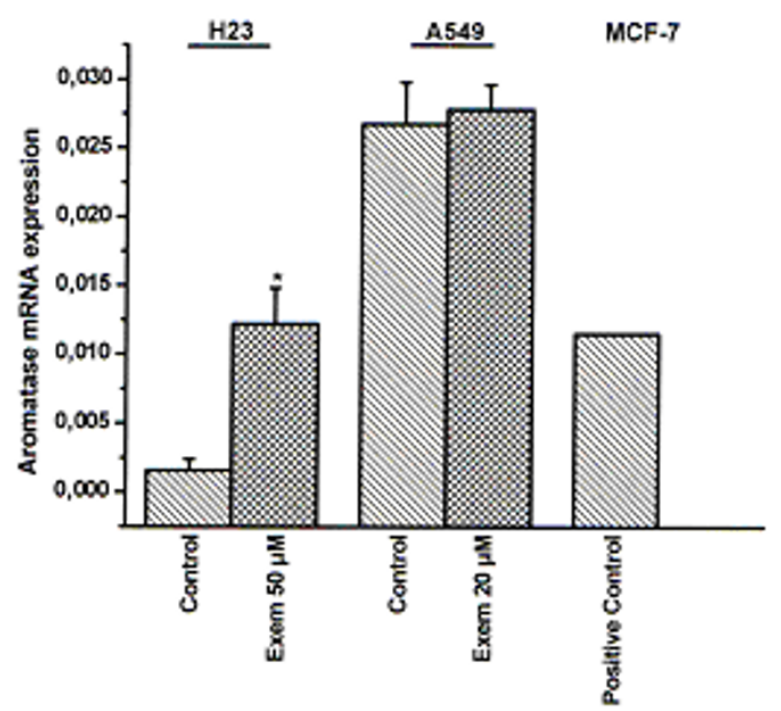

Figure 2

The effect of exemestane on mRNA levels of aromatase in $\mathrm{H} 23$ and $\mathrm{A} 549$ cells. $\mathrm{H} 23$ and $\mathrm{A} 549$ cells were treated with $50 \mu \mathrm{M}$ and $20 \mu \mathrm{M}$ exemestane respectively and $48 \mathrm{~h}$ later, aromatase mRNA levels were studied with real time RT-PCR. Results are expressed as relative expression and normalized to untreated cells. Asterisks denote a statistically significant difference (unpaired $t$-test) compared to untreated cells. $* P<0.05$.

reversed $30 \mathrm{~min}$ after the application of exemestane (Fig. $6)$.

\section{Localization and phosphorylation levels of EGFR in H23 and $\mathbf{A 5 4 9}$ cells}

Finally, we evaluated the effect of exemestane on EGFR localization and activation. In A549 cells, no changes in EGFR localization (Fig. 7) or phosphorylation (data not shown) were demonstrated following treatment of cells with exemestane. However, in H23 cells we found a translocation of EGFR from the cell membrane, $24 \mathrm{~h}$ after the addition of exemestane (Fig. 7). Moreover, we demonstrated an increase in EGFR activation, 15 min after treatment of $\mathrm{H} 23$ cells with exemestane (Fig. 8a and 8b). EGFR activation was detected using an Elisa kit assay (Fig. 8a), and the results were confirmed by immunoblot analysis (Fig. 8b).

\section{Discussion}

In the current study, we evaluated the activity of exemestane in NSCLC cell lines H23 and A549. Our results are in agreement with previous studies [5,7] which have reported that aromatase is expressed by NSCLC cells. Lung cancer cells may use estrogens produced via aromatase as a way to maintain or even increase the ER signaling [24]. We have also found that exemestane inhibited cell proliferation in both cell lines in a dose dependent manner and apoptosis was increased without affecting cell cycle. Previous reports have indicated that AIs such as anastrozole and letrozole may inhibit proliferation of the breast cancer cell line MCF-7 through induction of apoptosis and cell cycle arrest [21].

In order to determine the effective dose of exemestane regarding cell proliferation, a set of dose dependent experiments were performed. The dose dependent curves revealed that $50 \%$ growth inhibition was recorded at 50 $\mu \mathrm{M}$ for $\mathrm{H} 23$ and $20 \mu \mathrm{M}$ for A549 cells. Although the selected concentrations seem to be high, similar concentrations of an AI have also been used in previous studies for in vitro experiments $[7,25]$. The dose of exemestane currently used in clinical practice is $25 \mathrm{mg}$ daily. Exemestane exhibits an excellent safety profile in humans, having no significant toxicity at doses up to $600 \mathrm{mg} / \mathrm{day}$ and it is exceptionally well tolerated. The maximum tolerated dose and dose limiting toxicities have yet to be identified [26]. At a single dose of $25 \mathrm{mg}$, the average peak plasma level is $18 \mathrm{ng} / \mathrm{ml}$ (approximately $0.06 \mathrm{nM}$ ), within $2 \mathrm{~h}$ post dosing. This concentration is clearly lower compared to our in vitro experimental model, as well as to the majority of other in vitro experimental models. However, the aim of our study was to focus on the effect of exemestane on aromatase activity and EGFR signalling, when used at a dose with a significant effect on lung cancer cell proliferation.

In another study which also investigated the efficacy of an AI in NSCLC, aromatase activity was inhibited by anastrozole in NSCLC cell lines, and treatment of tumour cells with anastrozole led to suppression of cell growth [7]. It is of interest that the use of an aromatase inhibitor has the same effect on cell growth despite the different nature of the inhibitors used. In fact, anastrozole is a reversible nonsteroidal inhibitor whereas exemestane is an irreversible steroidal inactivator. In addition, our data provide information with respect to the effect of exemestane on protein and mRNA levels of aromatase in NSCLC cell lines.

Previous data regarding the effect of estradiol on the proliferation of $\mathrm{H} 23$ and A549 cells are contradictory. When estradiol was used at concentrations up to $1 \mu \mathrm{M}$, no effect on cell proliferation was demonstrated [27]. In contrast, estradiol enhanced cell proliferation when working concentrations were up to $20 \mu \mathrm{M}$ [7]. Therefore, we decided to treat both cell lines with various concentrations of testosterone, an aromatase substrate. We found that administration of testosterone did not affect the proliferation of cells. However, treatment with testosterone at higher doses was associated with a decrease in cell proliferation. 


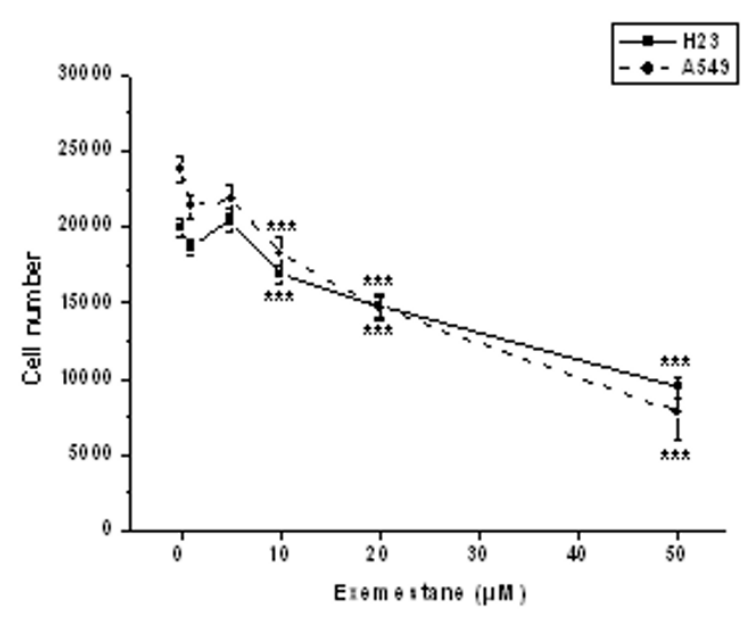

a

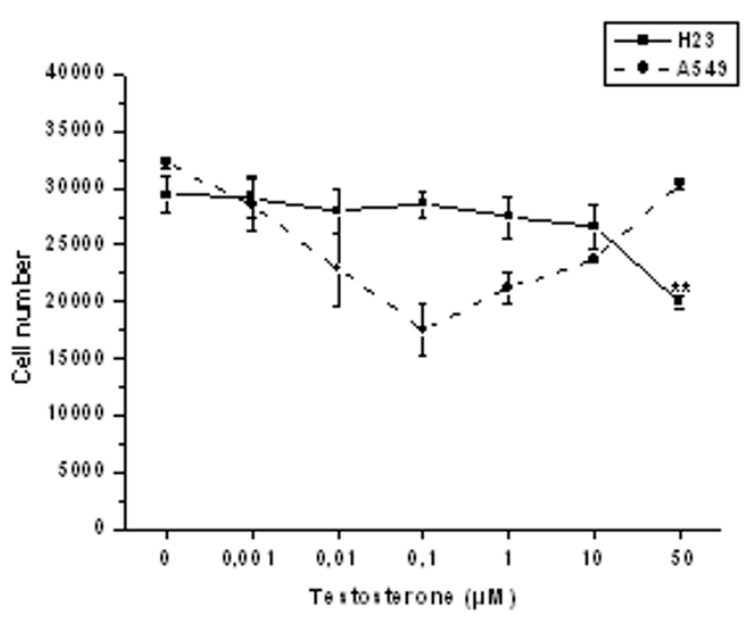

$\mathrm{b}$

\begin{abstract}
Figure 3
Dose response of a) exemestane and b) testosterone in $\mathrm{H} 23$ and A549 cells. Different doses of exemestane or testosterone were applied on $\mathrm{H} 23$ and A549 cells and $48 \mathrm{~h}$ later, the number of cells was estimated with the colorimetric MTT assay. Results are expressed as mean \pm SEM of the number of cells from at least three independent experiments performed in triplicates. Asterisks denote a statistically significant difference (unpaired $t$-test) compared to untreated cells. $* * p<0.0$ I and $* * * P<0.001$.
\end{abstract}

In view of the fact that testosterone is converted to estradiol by aromatase, the latter finding seems conflicting. However, previous reports have indicated that estrogens may reduce cell proliferation. Recent data suggest that estrogens are capable of inducing apoptosis in certain cell types, including breast cancer cells, immune system cells and bone-derived cells $[28,29]$.

Although exemestane showed a trend to inhibit aromatase activity $15 \mathrm{~min}$ after its application in both cell cultures, this inhibitory effect was reversed 6 h later. Previous reports with aminoglutethimide, an AI, also showed an increase in aromatase activity in breast cancer cell line SK-BR-3, choriocarcinoma cell line JAR, and in hepatocellular carcinoma HepG2 [30]. At least three mechanisms have been suggested. The first is that AIs can stabilize aromatase protein by forming enzyme-inhibitor complexes that slow down the degradation of the enzyme [31]. Indeed, we found an increase of aromatase protein levels in $\mathrm{H} 23$ cells. Another mechanism is that AIs can modulate aromatase expression at the transcription level [30]. In our study, we observed an increase of aromatase mRNA levels in $\mathrm{H} 23$ cells. On the other hand, we didn't find the same changes in protein and mRNA levels in A549 cells. The third possible mechanism includes changes in aromatase activity through a cAMP-dependent mechanism, without affecting mRNA or protein expression of the enzyme [30]. Indeed, in our study we demonstrated that treatment of cells with exemestane increased the levels of cAMP in both cell lines, $15 \mathrm{~min}$ after the application of the agent. These findings suggest that exemestane may increase the activity of aromatase through a cAMPdependent mechanism.

Although the decrease in aromatase activity was assessed 15 min following exemestane application, and this effect was reversed $6 \mathrm{~h}$ after the administration of the drug, changes in cell proliferation and aromatase protein and mRNA levels were measured $48 \mathrm{~h}$ after the addition of exemestane. Based on the information that the half life of aromatase protein is $28.2 \mathrm{~h}[32]$, we believe that the results from the inhibitory effect of exemestane could be observed $48 \mathrm{~h}$ after drug application.

In a recently reported study [24] that assessed the prognostic role of aromatase expression in NSCLC patients, lower levels of the enzyme predicted a higher probability of survival in women aged 65 years or older. These findings suggest that older female patients with NSCLC and high levels of aromatase might represent a group of patients where treatment with an AI could be beneficial. In our study, we showed that the cell line A549, which expresses higher aromatase protein and mRNA levels might be a better target for exemestane, since aromatase 

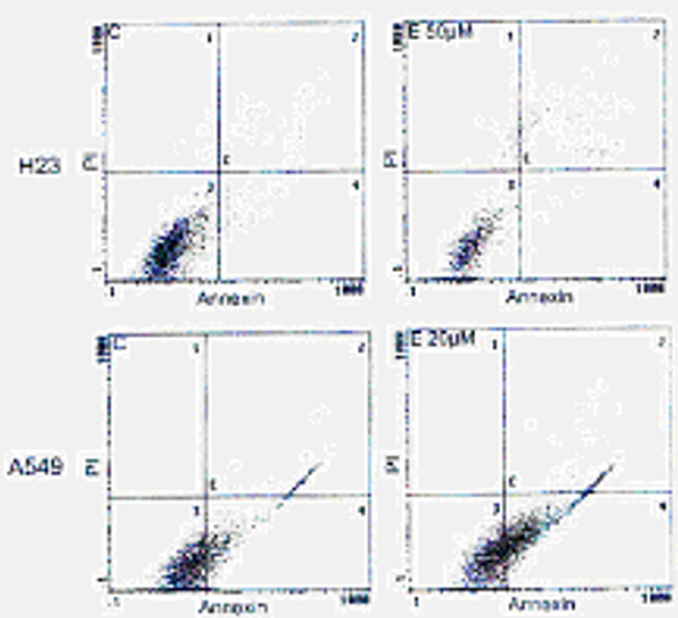

A

\section{Figure 4}

The effect of exemestane on apoptosis of $\mathbf{H} 23$ and A549 cells. A: Flow cytometry analysis of $\mathrm{H} 23$ and A549 following exposure to exemestane. A representative image from three independent experiments is shown. $\mathrm{H} 23$ cells. $\mathrm{C}$ : Control and $\mathrm{E}$ $50 \mu \mathrm{M}$ : Exemestane $50 \mu \mathrm{M}$. A549 cells. C: Control and E $20 \mu \mathrm{M}$ : Exemestane $20 \mu \mathrm{M}$. B: Results are expressed as the \% percentage of Annexin ${ }^{+}$cells \pm SEM compared to untreated cells from at least three independent experiments. Asterisks denote a statistically significant difference (unpaired $t$-test) compared to untreated cells (C). $* * P<0.0 \mathrm{I}$ and $* * * P<0.00 \mathrm{I}$.

expression was not increased by this agent, in contrast to the cell line H23 with lower aromatase levels. Moreover, fifty percent growth inhibition was recorded at $50 \mu \mathrm{M}$ for H23 and $20 \mu \mathrm{M}$ for A549 cells.

Finally, we found that the administration of exemestane in $\mathrm{H} 23$ cells was associated with EGFR activation, 15 min after drug application. Current evidence suggests that cross-talk between steroid receptors and growth factor receptors exists in a bidirectional way. In addition, significant interactions between estrogen signaling and EGFR have been recognized not only in breast, but also in NSCLC [5]. Exemestane may affect EGFR pathway independently of aromatase inhibition. It has been demonstrated that exemestane can activate ER [33] which in turn leads to the production of the EGFR ligand amphiregulin, resulting in EGFR activation [34]. This mechanism may be implicated in exemestane resistance and may also be involved in exemestane-induced EGFR activation found in our study. Other interactions between growth factor signaling pathways and aromatase in NSCLC have also been reported [35]. The effect of exemestane on EGFR activation observed in our study also suggests that this agent may be less effective in H23 cells, compared to A549 cells. In addition, the combination of exemestane with an anti-EGFR agent may represent a more efficient option in H23 cells. Recently, we investigated the dual inhibition of aromatase and EGFR in NSCLC cell lines using exemestane and the EGFR tyrosine kinase inhibitor erlotinib. In agreement with the aforementioned results, the combination of exemestane and erlotinib was more effective than each agent alone, in H23 cells [36].

The activation of EGFR followed by its translocation may lead to receptor internalization and proteolytic degradation [37]. Alternatively, EGFR has been detected in caveolae, Golgi complex, endoplasmatic reticulum, lysosomelike structures, nuclear envelope, nucleus and mitochondria [38,39]. In addition, it has been demonstrated that EGFR mitochondrial localization is implicated in cell survival [39]. In agreement with this observation, unpublished data from our laboratory confirmed the translocation of EGFR to mitochondria in $\mathrm{H} 23$ cells, following treatment with exemestane. Moreover, this translocation was inhibited by the concurrent administration of erlotinib.

In summary, our results suggest that exemestane might elevate estradiol levels in both cell lines through a cAMPdependent mechanism. In addition, exemestane enhances estradiol levels in $\mathrm{H} 23$ cells through an increase in mRNA and protein levels of aromatase. However, the antiproliferative effect of exemestane through induction of apoptosis remains to be elucidated. A recent report demonstrated 

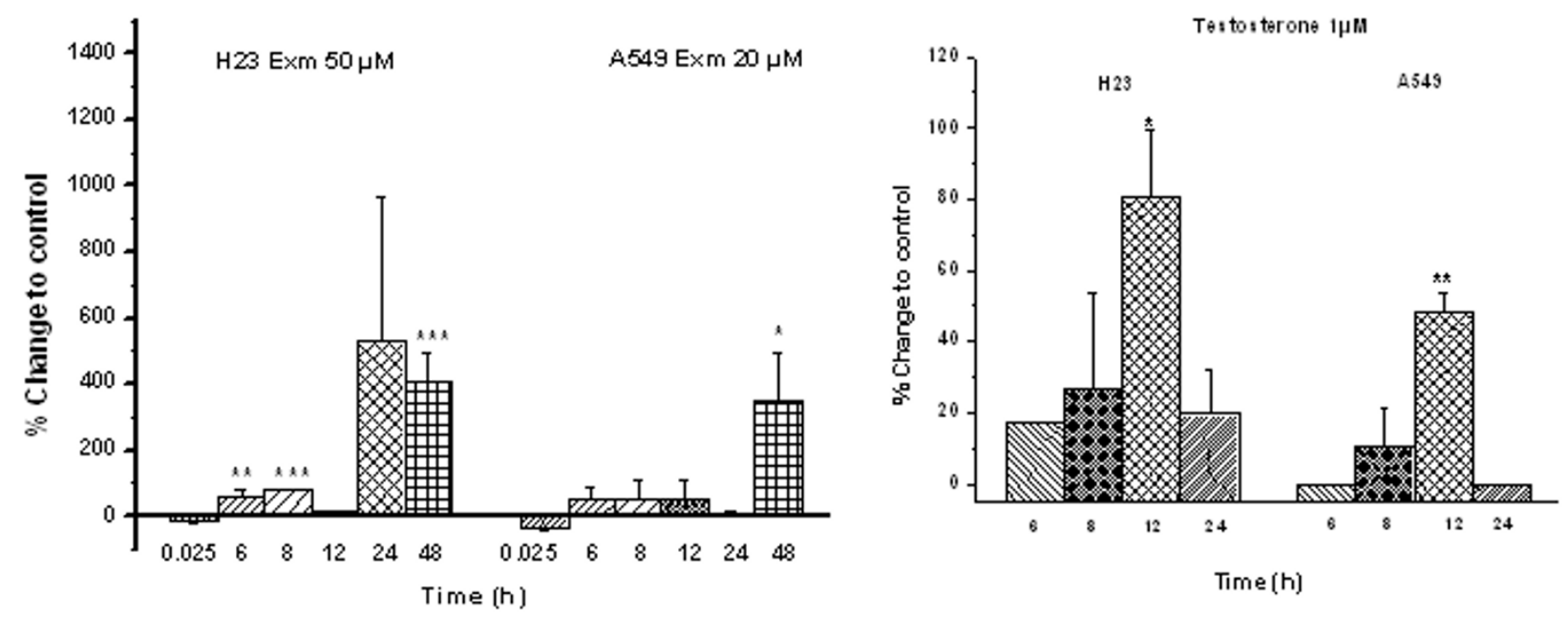

a

\section{Figure 5}

The effect of a) exemestane and b) testosterone on aromatase activity of $\mathrm{H} 23$ and A549 cells. H23 and A549 cells were treated with $50 \mu \mathrm{M}$ and $20 \mu \mathrm{M}$ exemestane, respectively and both cell lines were treated with I $\mu \mathrm{M}$ testosterone. At the time points of $15 \mathrm{~min}, 6,8,12,24$ and $48 \mathrm{~h}$, samples were analysed as described in Methods. $* P<0.05, * * P<0.01$ and $* * * P<$ 0.001 .

that high concentrations of estradiol, under low growth stimulated conditions, decrease cell proliferation and increase apoptosis in breast cancer cells through the sustained activation of JNK pathway [40]. Indeed, our experiments were performed under low growth stimulated conditions which mimic the low estrogenic milieu in postmenopausal women [40]. This mechanism may represent a possible explanation for the antiproliferative effect of exemestane in both NSCLC cell lines, found in our study.

\section{Conclusion}

In conclusion, our study provides evidence that aromatase is expressed by NSCLC cells and exemestane inhibits cell proliferation. Moreover, levels of aromatase expression might have a predictive ability in the activity of this agent, since exemestane may activate EGFR pathway in cells with low levels of aromatase. Further studies are needed to investigate the effectiveness of exemestane in NSCLC and evaluate the potential for incorporating AIs in the management of lung cancer patients.

\section{Methods}

Cell culture and reagents

NSCLC cell lines H23 and A549, and control breast cancer cell line MCF-7 were purchased from American Type Culture Collection (ATCC). H23 and A549 cells were cultured in RPMI 1640 medium with 2 mM L-glutamine and supplemented with $1 \mathrm{mM}$ sodium pyruvate, $4.5 \mathrm{~g} / \mathrm{L}$ glucose, $1.5 \mathrm{~g} / \mathrm{L}$ sodium bicarbonate and 10\% fetal bovine serum. MCF-7 cells were cultured in Eagle's Minimum Essential medium (EMEM) with Earle's BSS and $2 \mathrm{mM}$ L-glutamine and supplemented with $1.0 \mathrm{mM}$ sodium pyruvate, 0.1 $\mathrm{mM}$ nonessential amino acids, $1.5 \mathrm{~g} / \mathrm{L}$ sodium bicarbonate, $0.01 \mathrm{mg} / \mathrm{ml}$ bovine insulin and $10 \%$ fetal bovine serum. Cells were cultured at $37^{\circ} \mathrm{C}, 5 \% \mathrm{CO}_{2}$ and $100 \%$ humidity.

The aromatase inhibitor exemestane (Aromasin) was kindly provided by Pfizer. Exemestane was applied to cell lines after cell attachment at doses of 1, 5, 10, 20 and 50 $\mu \mathrm{M}$. Testosterone was purchased by Sigma (Sigma, Steinheim, Germany) and was applied to cell lines after cell attachment at doses of $0.001,0.01,0.1,1,10$ and $50 \mu \mathrm{M}$. Exemestane was diluted in dimethyl sulfoxide (DMSO) and testosterone was diluted in ethanol. The final concentration of both DMSO and ethanol in culture medium was 


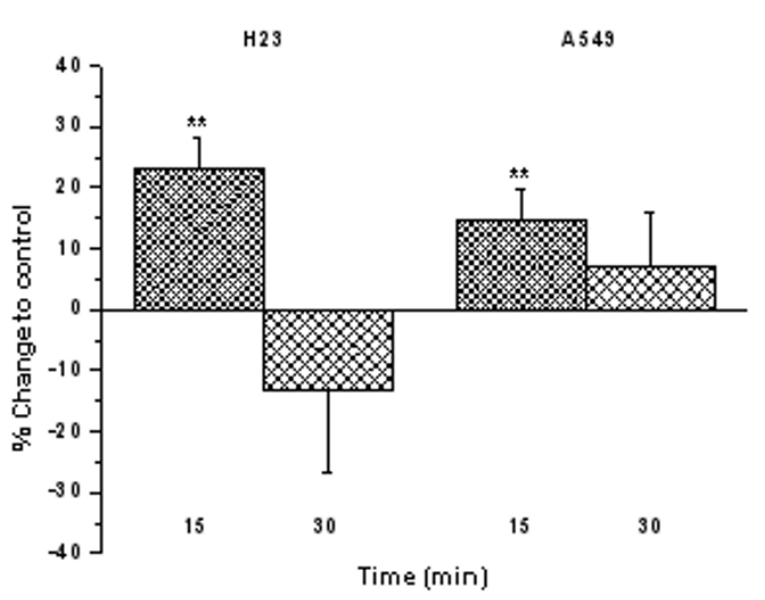

\section{Figure 6}

The effect of exemestane on CAMP levels in $\mathrm{H} 23$ and A549 cells. $\mathrm{H} 23$ and $\mathrm{A} 549$ cells were treated with $50 \mu \mathrm{M}$ and $20 \mu \mathrm{M}$ exemestane, respectively. At the time points of 15 and $30 \mathrm{~min}$, samples were analysed as described in Methods. ** $P<0.01$.

0.5\%. After reaching 50\% confluence, cells were washed with phosphate buffer saline (PBS) and incubated with phenol red-free medium with $1 \%$ dextran-coated, charcoal-treated FBS (working medium) for $24 \mathrm{~h}$ to deplete estrogen [7]. All the experiments were performed according to these conditions. Thereafter, cells were treated with exemestane or testosterone at the indicated time points and doses.

\section{Immunoblotting}

Cells were plated at Petri dishes. After reaching 80\% confluence, cells were treated with working medium as described above. Forty eight hours after exemestane addition, cells were collected with scrapper and lysed using appropriate lysis buffer (50 mM Tris- $\mathrm{HCl}$ pH 7.5, $150 \mathrm{mM}$ $\mathrm{NaCl}, 5 \mathrm{mM}$ EDTA, 1\% Triton, 10\% glycerol, $1 \mathrm{mM}$ phenylmethyl-sulphonyl-fluoride, $2 \mathrm{mM}$ Na-orthovanadate and $10 \mathrm{mM}$ leupeptin). Protein concentration was determined by Bradford assay. Samples were analyzed by immunoblotting as described previously [7]. Actin was used as control. A goat polyclonal anti-aromatase antibody (CYP19) C16 (dilution 1:5000, Santa Cruz, CA, USA) and a monoclonal anti-actin antibody were used (dilution 1:1000, Chemicon, Millipore, Temecula, CA, USA). For the detection of phosphorylated EGFR/EGFR, an immunoprecipitation was performed prior to immunoblotting. Briefly, cells were prepared as described above. Fifteen minutes after the addition of exemestane, cells were collected with scrapper and lysed with sonication (3 cycles for 5 sec each, MSE PG 616) using the same lysis buffer as above. Protein concentration was determined and $1 \mathrm{mg}$ total protein was immunoprecipitated with a monoclonal anti- EGFR antibody (dilution $1 \mu \mathrm{g}$ per $0.5 \mathrm{mg}$ of total protein, 3H2094, Santacruz, CA, USA), overnight at $4{ }^{\circ} \mathrm{C}$ under continuous agitation. In each sample, $50 \mu$ l of protein-A sepharose beads (Calbiochem, Merck, Dermstadt, Germany) were added and samples were incubated for $4 \mathrm{~h}$, at $4^{\circ} \mathrm{C}$ under continuous agitation. Precipitates were washed twice with ice-cold lysis buffer and sepharose beads were resuspended in $50 \mu \mathrm{l} 2 \times$ sample buffer (0.5 M Tris- $\mathrm{HCl}$ pH 6.8, 20\% glycerol, 2\% SDS and 2\% bromophenol blue, $10 \%$ b-mercaptoethanol). Samples were heated for $5 \mathrm{~min}$ at $95^{\circ} \mathrm{C}$ and analyzed by immunoblotting. A monoclonal anti-tyrosine antibody (dilution $2 \mu \mathrm{g} / \mathrm{ml}$, Upstate, Lake Placid, NY, USA) and a monoclonal anti-EGFR antibody (dilution 1:200, 3H2094, Santacruz, CA, USA) were used. Detection of immunoreactive proteins was performed by chemiluminescence using horseradish peroxidase substrate SuperSignal (Pierce, Rockford, IIL, USA), according to manufacturer's instructions.

\section{RNA isolation and CDNA synthesis}

Total RNA was extracted from cells using Absolutely RNA RT-PCR kit (Stratagene, La Jolla, USA) according to the manufacturer's instructions. Integrity of RNA was confirmed by visualization of ribosomal bands by EtBrstained agarose gel electrophoresis. RNA was quantified using Ribogreen (Molecular Probes, Leiden, the Netherlands) and the MX3000p (Stratagene, La Jolla, USA) according to manufacturer's instructions. First strand cDNA was synthesized as previously described [41].

\section{Real time PCR}

Quantification of cyp19 mRNA was performed using gene-specific primers (F: 5'-AACAACTCGACCCTTCTTTATG-3', R: 5'-TTTGAGGGATTCAGCACAG-3') and SYBR Green I intercalation dye in Brilliant Sybr Green QPCR Master Mix (Stratagene, La Jolla, USA). Expressed Alu-Sq repeat levels were also similarly quantified using primers designed by Dr J. Vandesompele, Gent University Hospital, Belgium. In addition, a standard curve was included in each run for assay validation. Reactions were performed as previously described [41]. Cyp19 mRNA levels were normalised to Alu-Sq levels which were found to be unaffected by exemestane treatment.

\section{Cell proliferation assay}

To determine whether exemestane or testosterone affect the proliferation of H23 and A549 NSCLC cell lines, the 3- [4,5-dimethylthiazol-2-yl]-2,5-dimethyltetrazolium bromide (MTT) assay was used, as previously described [42]. Briefly, cells were plated at a density of $2 \times 10^{4}$ cells per well in 24-well tissue culture plates. The medium was aspirated later at $24 \mathrm{~h}$, cells were washed twice with phos- 


\section{A549}
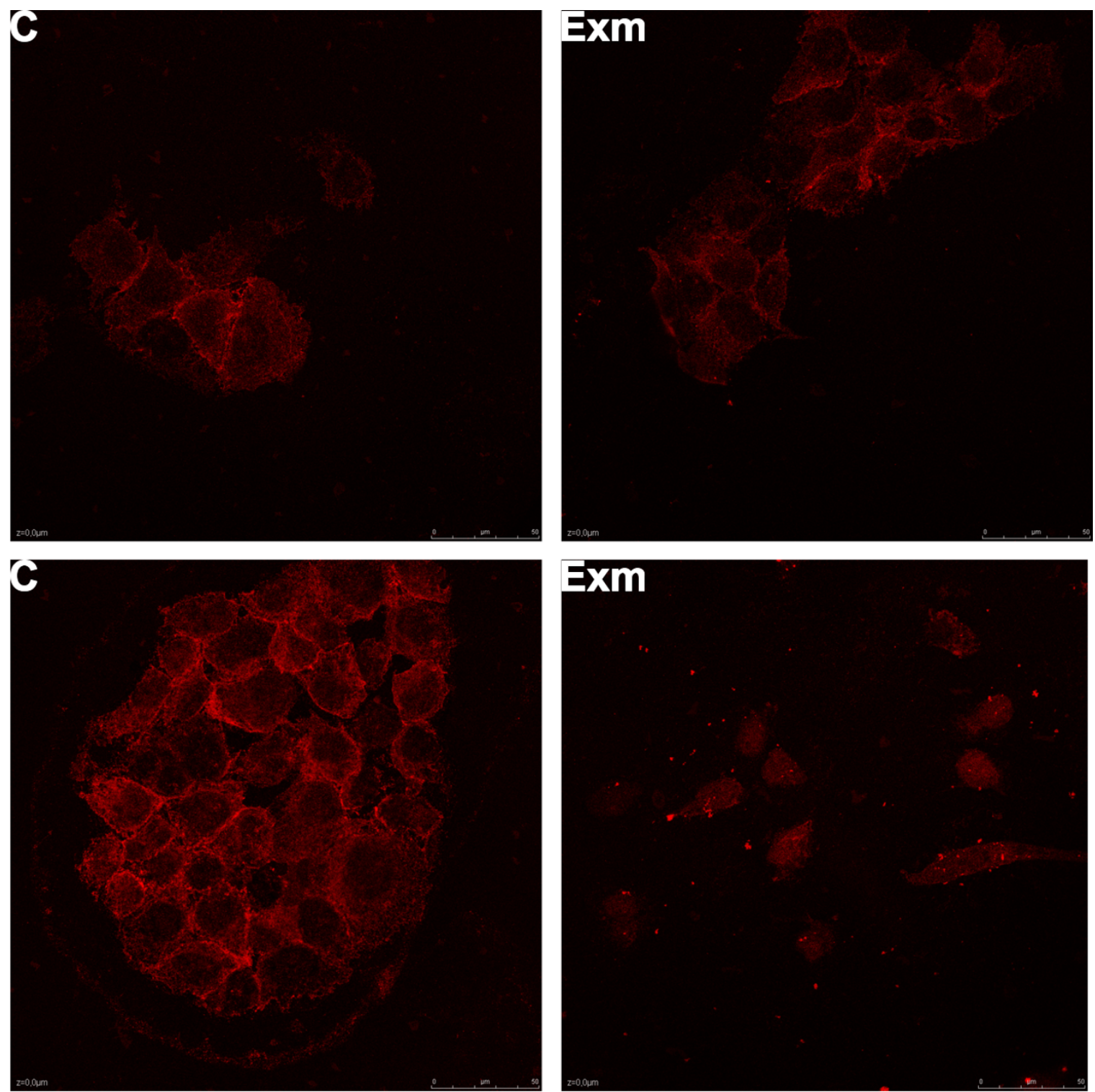

Figure 7

The effect of exemestane on EGFR localization in $\mathbf{H 2 3}$ and A549 cells. Both cell lines were treated with $50 \mu$ M and $20 \mu \mathrm{M}$ exemestane, respectively. At the time point of $24 \mathrm{~h}$, samples were analyzed as described in Methods. The figure is a representative from at least three independent experiments (magnification at 60x).

phate buffer saline (PBS) and $0.5 \mathrm{ml}$ of working medium was added in each well. After a $24 \mathrm{~h}$ incubation exemestane or testosterone was added into cells. Cell proliferation was measured $48 \mathrm{~h}$ after exemestane addition using MTT assay. MTT stock ( $5 \mathrm{mg} / \mathrm{ml}$ in PBS) at a volume equal to $1 / 10$ of the medium was added and plates were incubated at $37^{\circ} \mathrm{C}$ for $2 \mathrm{~h}$. The medium was removed, the cells were washed with PBS pH 7.4 and $100 \mu$ lacidified isopropanol $(0.33 \mathrm{ml} \mathrm{HCl}$ in $100 \mathrm{ml}$ isopropanol) was added to each well and agitated thoroughly in order to solubilise the dark blue formazan crystals. The solution was transferred to 96-well plates and immediately read on a micro- plate reader (Tecan, Sunrise, Magellan 2) at a wavelength of $570 \mathrm{~nm}$. Results were always confirmed by direct measurements of the cells using a standard Neubauer haemocytometer.

\section{Apoptosis assay}

Both NSCLC cell lines were plated at $1 \times 10^{5}$ cells per well in 6-well plates. Exemestane was added as previously described. At the end of a $48 \mathrm{~h}$ incubation, cells were washed twice with PBS, trypsinized for $6 \mathrm{~min}$ and centrifuged for $4 \mathrm{~min}$ at $166 \mathrm{~g}$. Cells were resuspended in $200 \mu \mathrm{l}$ $1 \times$ binding buffer (10 mM HEPES pH 7.4, $140 \mathrm{mM} \mathrm{NaCl}$, 


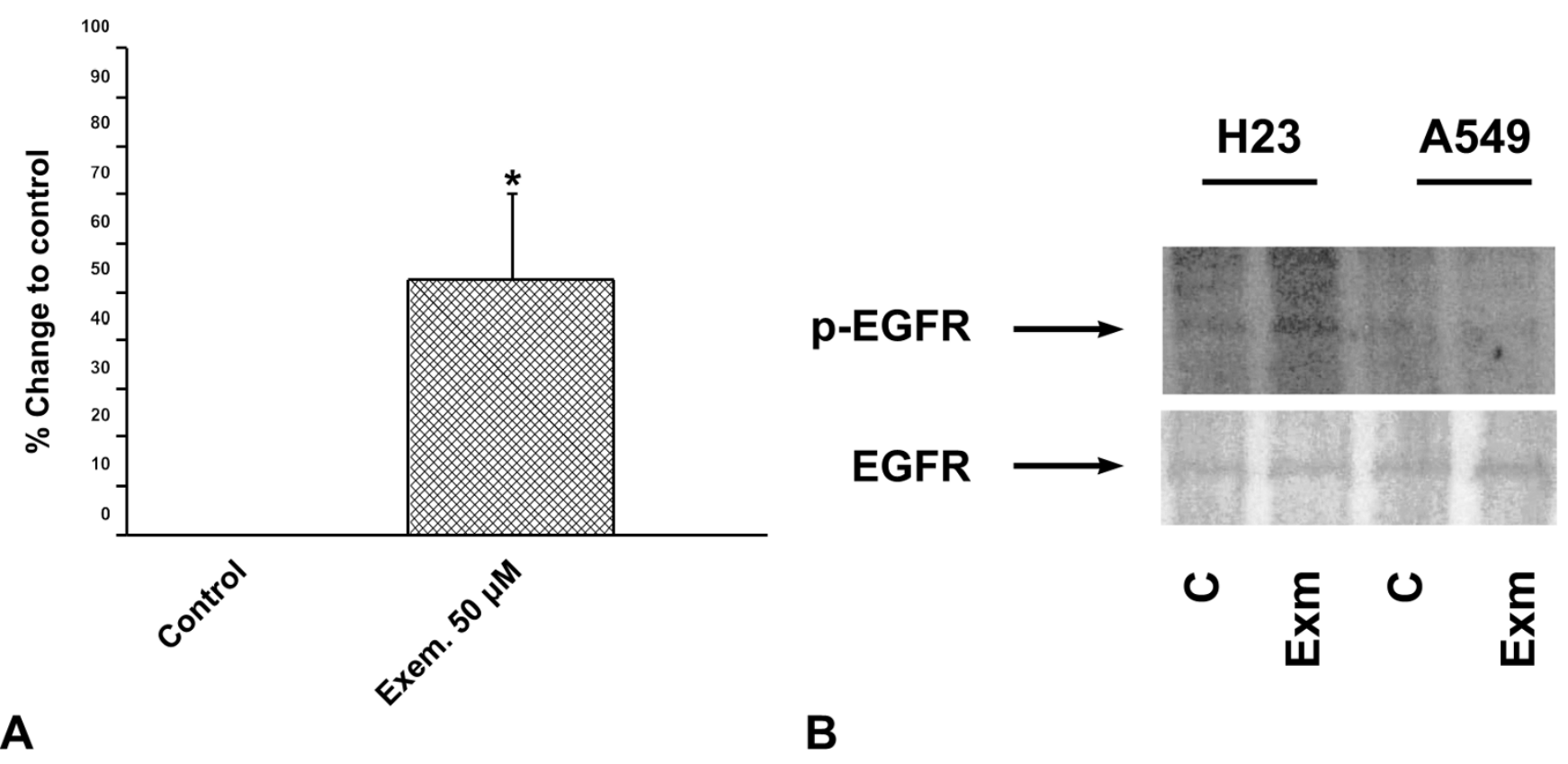

Figure 8

The effect of exemestane on EGFR phosphorylation a) in H23 cells using an ELISA kit assay and b) in H23 and A549 cells using immunoblotting. $\mathrm{H} 23$ and A549 cells were treated with $50 \mu \mathrm{M}$ and $20 \mu \mathrm{M}$ exemestane, respectively and I 5 min later they were analyzed as described in Methods. C: untreated cells (H23 or A549 cells) and Exm: H23 or A549 cells treated with $50 \mu \mathrm{M}$ or $20 \mu \mathrm{M}$ exemestane, respectively. $* \mathrm{P}<0.05$.

$2.5 \mathrm{mM} \mathrm{CaCl}_{2}$ ). The cell suspension was incubated with 5 $\mu \mathrm{l}$ Annexin V-FITC in the dark at $25^{\circ} \mathrm{C}$, for $10 \mathrm{~min}$. Then, $10 \mu \mathrm{l}$ of the $20 \mu \mathrm{g} / \mathrm{ml}$ propidium iodide stock solution was added, followed by $400 \mu \mathrm{l}$ of binding buffer and cells were immediately analyzed by flow cytometry [43] (EPICS-XL of Coulter) according to manufacturer's instructions (rh Annexin V/FITC kit, Bender MedSystems).

\section{Aromatase activity}

Aromatase activity was estimated through measurement of estradiol production by ELISA (IBL Hamburg, Germany) according to manufacturer's instructions at 450 nm with a microplate reader (Tecan, Sunrise, Magellan 2). Briefly, cells were plated at $2 \times 10^{4}$ cells per well in 24 -well plates. Exemestane or testosterone was added as previously described. At several time points after incubation $(0.25,6,8,12,24$ and $48 \mathrm{~h})$, supernatants were collected and stored at $-20^{\circ} \mathrm{C}$ until the end of the experiment. Twenty five $\mu \mathrm{l}$ of each sample was added into well that was pre-coated with a polyclonal antibody against estradiol molecule. Then $200 \mu$ l of appropriate enzyme conjugate was added to each well and an incubation of $2 \mathrm{~h}$ was followed. After the incubation, wells were washed 3 times with wash solution and $100 \mu$ l of suitable substrate solution was added to each well. Fifteen minutes later, the enzymatic reaction was stopped by adding $50 \mu$ l of stop solution. The absorbance of each well was measured at $450 \mathrm{~nm}$ with a microplate reader within $10 \mathrm{~min}$ after add- ing the stop solution. An appropriate standard curve was determined.

\section{cAMP detection}

The cAMP levels were measured using an ELISA kit assay (R\&D Systems Europe, Ltd, UK). Samples were prepared according to manufacturer's instructions. Briefly, H23 and A549 cells were plated in Petri dishes. After reaching 50\% confluence, cells were treated with working medium as described above and $24 \mathrm{~h}$ later exemestane was added into cells. Supernatants were removed 15 and $30 \mathrm{~min}$ later and cells were washed 3 times with cold PBS. Then, cells were resuspended in cell lysis buffer $5(1 \times)$ that was included in kit to a concentration of $1 \times 10^{7}$ cells $/ \mathrm{ml}$. Cells were freezed at $\leq-20^{\circ} \mathrm{C}$ and thawed with gentle mixing. The cycle of freeze/thaw was repeated once. Samples were centrifuged at $600 \times \mathrm{g}$ for $10 \mathrm{~min}$ at $4^{\circ} \mathrm{C}$ to remove cellular debris. Samples were stored at $-20^{\circ} \mathrm{C}$ until their use. Suitable microplate containg pre-coated wells with goat antimouse antibody, was incubated with $50 \mu \mathrm{l}$ of a monoclonal antibody specific for CAMP for $1 \mathrm{~h}$ at room temperature. After the incubation, wells were washed 3 times with wash solution and $100 \mu \mathrm{l}$ of each sample was added to each well. Then, $50 \mu$ l of cAMP congjugate was added to all wells and an incubation of $2 \mathrm{~h}$ was followed. After a step of 3 washes, $200 \mu$ l of a substrate solution was added to each well and an incubation of $30 \mathrm{~min}$ in dark was followed. Then, $100 \mu \mathrm{l}$ of stop solution was added to each 
well. The absorbance of each well was measured at 450 $\mathrm{nm}$ with correction at $570 \mathrm{~nm}$ in a microplate reader (Tecan, Sunrise, Magellan 2) within 30 min after adding the stop solution. An appropriate standard curve was determined.

\section{Immunofluorescense}

Both NSCLC cell lines were treated with exemestane as previously described. Twenty four hours later, medium was removed and cells were washed twice with PBS. Cells were fixed with a $4 \%$ paraformaldehyde in PBS buffered solution for $10 \mathrm{~min}$ at room temperature and then they were rinsed $3 \times 5 \mathrm{~min}$ with PBS. An incubation of $1 \mathrm{~h}$ was followed by a $3 \%$ BSA solution supplemented with $10 \%$ FBS at $37^{\circ} \mathrm{C}$. After the incubation with blocking solution, cells were rinsed once with PBS for $5 \mathrm{~min}$ and they were treated overnight at $4^{\circ} \mathrm{C}$ with a monoclonal anti-EGFR antibody diluted in blocking solution $(10 \mu \mathrm{g} / \mathrm{ml}$, Upstate, Lake Placid, NY, USA, ). Cells were rinsed $3 \times 5$ min with PBS and then an anti-mouse antibody conjugated with Alexa Fluor 594 (1:500, Invitrogen, Molecular probe) diluted in blocking solution was added for $30 \mathrm{~min}$ at $37^{\circ} \mathrm{C}$. Cells were rinsed $3 \times 5$ min with PBS and mounted on glass sides. Fluorescence was visualized using a Leica microscope.

\section{EGFR phosphorylation}

The levels of phosphorylated EGFR were determined using an ELISA kit system (Bender MedSystems GmbH, Austria), according to the manufacturer's instructions. Briefly, cells were seeded in $100 \mathrm{~mm}$ petri dishes at a density of $10^{6}$ cells per dish and were treated as previously described. Fifteen minutes after the addition of exemestane, supernatants were removed and cells were collected with scraper. Lysis of cells was followed by adding receptor binding buffer. Samples were transferred onto 96microwell plate coated with a monoclonal antibody to human active EGFR and incubated for $1 \mathrm{~h}$ at $37^{\circ} \mathrm{C}$. Microwells were emptied and washed three times with washing buffer. An anti-phosphotyrosine monoclonal antibody (horseradish peroxidase conjugated) was added and samples were incubated for $1 \mathrm{~h}$ at $37^{\circ} \mathrm{C}$. Microwells were washed four times and a suitable substrate solution was added to each sample for $15 \mathrm{~min}$. The reaction was stopped by adding a stop solution and the samples were immediately measured on a microplate reader (Tecan, Sunrise, Magellan 2) at a wavelength of $450 \mathrm{~nm}$. The results were normalized by measuring the amount of total proteins using Bradford assay, since total protein amount is not altered for the time point of $15 \mathrm{~min}$ after exemestane addition.

\section{Statistical analysis}

Differences between groups and controls were tested by unpaired $t$-test. Each experiment included at least tripli- cate measurements. All results are expressed as mean \pm SEM from at least three independent experiments.

\section{Competing interests}

The authors declare that they have no competing interests.

\section{Authors' contributions}

AKK participated in the conception, design and coordination of the study, interpretation of data, and drafted the manuscript. EG participated in the design of the study and interpretation of data, performed the analyses, and was involved in drafting the manuscript. KI and AA contributed to the analyses and interpretation of data. TRJE and AGP critically revised the manuscript. HPK participated in the design and coordination of the study. All authors have read and approved the final version of the manuscript.

\section{Acknowledgements}

EG and AA were supported by the Hellenic Cooperative Oncology Group (HeCOG).

\section{References}

I. Taioli E, Wynder EL: Re: Endocrine factors and adenocarcinoma of the lung in women. I Natl Cancer Inst I994, 86:869-870.

2. Omoto $Y$, Kobayashi $Y$, Nishida K, Tsuchiya E, Eguchi H, Nakagawa K, Ishikawa Y, Yamori T, Iwase H, Fujii Y, Warner M, Gustafsson JA, Hayashi SI: Expression, function, and clinical implications of the estrogen receptor $\beta$ in human lung cancers. Biochem Biophys Res Commun 200I, 285:340-347.

3. Stabile LP, Davis AL, Gubish CT, Hopkins TM, Luketich JD, Christie $N$, Finkelstein S, Siegfried JM: Human non-small cell lung tumours and cells derived from normal lung express both estrogen receptor alpha and beta and show biological responses to estrogen. Cancer Res 2002, 62:2|4|-2150.

4. Stabile LP, Lyker JS, Gubish CT, Zhang W, Grandis JR, Siegfried JM: Combined targeting of the estrogen receptor and the epidermal growth factor receptor in non-small cell lung cancer shows enhanced antiproliferative effects. Cancer Res 2005, 65: 1459-1470.

5. Pietras RJ, Marquez DC, Chen HW, Tsai E, Weinberg O, Fishbein M: Estrogen and growth factor receptor interactions in human breast and non-small cell lung cancer cells. Steroids 2005, 70:372-38I.

6. Hershberger PA, Vasquez AC, Kanterewicz B, Land S, Siegfried JM, Nichols $M$ : Regulation of endogenous gene expression in human non-small cell lung cancer cells by estrogen receptor ligands. Cancer Res 2005, 65:1598-1605.

7. Weinberg OK, Marquez-Garban DC, Fishbein MC, Goodglick L, Garban HJ, Dubinett SM, Pietras RJ: Aromatase inhibitors in human lung cancer therapy. Cancer Res 2005, 65: I I287-I I29I.

8. Dubey S, Siegfried JM, Traynor AM: Non-small-cell lung cancer and breast carcinoma: chemotherapy and beyond. Lancet Oncol 2006, 7:416-424.

9. Marquez-Garban DC, Chen HW, Fishbein MC, Goodglick L, Pietras $\mathrm{RJ}$ : Estrogen receptor signalling pathways in human nonsmall cell lung cancer. Steroids 2007, 72:135-| 43.

10. Fasco MJ, Hurteau GJ, Spivack SD: Gender-dependent expression of alpha and beta estrogen receptors in human non-tumor and tumor lung tissue. Mol Cell Endocrinol 2002, I 88: | 25-|40.

II. Stabile LP, Siegfried JM: Estrogen receptor pathways in lung cancer. Curr Oncol Rep 2004, 6:259-267.

12. Schabath MB, Wu X, Vassilopoulou-Sellin R, Vaporciyan AA, Spitz $M R$ : Hormone replacement therapy and lung cancer risk: a case-control analysis. Clin Cancer Res 2004, I 0: I I 3-I23.

13. Ganti AK, Sahmoun AE, Panwalkar AW, Tendulkar KK, Potti A: Hormone replacement therapy is associated with decreased survival in women with lung cancer. J Clin Oncol 2006, 24:59-63. 
14. Hede K: Lung cancer may be different for men and women, but researchers ponder what to do? J Natl Cancer Inst 2007, 99:1830-1832.

15. Yang $\mathrm{CH}$, Cheng $\mathrm{AL}$, Yeh KH, Yu CJ, Lin JF, Yang PC: High dose tamoxifen plus cisplatin and etoposide in the treatment of patients with advanced, inoperable non small cell lung carcinoma. Cancer 1999, 86:4I5-420.

16. Chen Y, Perng RP, Yang KY, Lin WC, Wu HW, Tsai CM, Whang-Peng J: Phase II study of tamoxifen, ifosfamide, epirubicin and cisplatin combination chemotherapy in patients with non-small cell lung cancer failing previous chemotherapy. Lung Cancer 2000, 29:139-146.

17. Patel JD, Gray RG, Stewart JA, Skinner HG, Schiller JH: Tamoxifen does not reduce the risk of lung cancer in women [abstract]. J Clin Oncol 2005, 23:72 I 2 .

18. Traynor AM, Schiller JH, Stabile LP, Kolesar JM, Eickhoff JC, Dacic S, Hoang T, Dubey S, Marcotte SM, Siegfried JM: Pilot study of gefitinib and fulvestrant in the treatment of post-menopausal women with advanced non-small cell lung cancer. Lung Cancer 2009, 64:5I-59.

19. Hong Y, Yu B, Sherman M, Yuan YC, Zhou D, Chen S: Molecular basis for the aromatization reaction and exemestane mediated-irreversible inhibition of human aromatase. Mol Endocrinol 2007, 2 I:40I-4I4.

20. Coombes RC, Hall E, Gibson LJ, Paridaens R, Jassem J, Delozier T, Jones SE, Alvarez I, Bertelli G, Ortmann O, Coates AS, Bajetta E, Dodwell D, Coleman RE, Fallowfield LJ, Mickiewicz E, Andersen J, Lønning PE, Cocconi G, Stewart A, Stuart N, Snowdon CF, Carpentieri M, Massimini G, Bliss JM, Velde $C$ van de, Intergroup Exemestane Study: A randomized trial of exemestane after two or three years of tamoxifen therapy in postmenopausal women with primary breast cancer. N Engl J Med 2004, 350:1081-1092.

21. Thiantanawat A, Long B, Brodie A: Signaling pathways of apoptosis activated by aromatase inhibitors and antiestrogens. Cancer Res 2003, 63:8037-8050.

22. Giudici D, Ornati G, Briatico G, Buzzetti F, Lombardi P, di Salle E: 6Methylenandrosta-I,4-diene-3,I7-dione (FCE 24304): a new irreversible aromatase inhibitor. J Steroid Biochem 1988, 30:391-394.

23. Santner SJ, Pauley RJ, Tait L, Kaseta J, Santen RJ: Aromatase activity and expression in breast cancer and benign breast tissue stromal cells. J Clin Endocrinol Metab 1997, 82:200-208.

24. Mah V, Seligson DB, Li A, Marquez DC, Wistuba II, Elshimali Y, Fishbein MC, Chia D, Pietras RJ, Goodglick L: Aromatase expression predicts survival in women with early-stage non-small cell lung cancer. Cancer Res 2007, 67:10484-10490.

25. Miller WR: Biology of aromatase inhibitors: pharmacologyl endocrinology within the breast. Endocr Relat Cancer 1999, 6:187-195.

26. Brueggemeier RW: Overview of the pharmacology of the aromatase inactivator exemestane. Breast Cancer Res Treat 2002, 74:177- 185 .

27. Dougherty SM, Mazhawidza W, Bohn AR, Robinson KA, Mattingly KA, Blankenship KA, Huff MO, McGregor WG, Klinge CM: Gender difference in the activity but not expression of estrogen receptors alpha and beta in human lung adenocarcinoma cells. Endocr Relat Cancer 2006, 13:1 I3-134.

28. Jordan VC, Lewis JS, Osipo C, Cheng D: The apoptotic action of estrogen following exhaustive antihormonal therapy: a new clinical treatment strategy. Breast 2005, 14:624-630.

29. Song RX, Santen RJ: Apoptotic action of estrogen. Apoptosis 2003, 8:55-60.

30. Chen S, Zhou D, Yang C, Okubo T, Kinoshita Y, Yu B, Kao YC, Itoh $\mathrm{T}$ : Modulation of aromatase expression in human breast tissue. J Steroid Biochem Mol Biol 200I, 79:35-40.

31. Harada N, Hatano O: Inhibitors of aromatase prevent degradation of the enzyme in cultured human tumor cells. Br J Cancer 1998, 77:567-572.

32. Wang $X$, Chen S: Aromatase Destabilizer: Novel Action of Exemestane, a Food and Drug Administration-Approved Aromatase Inhibitor. Cancer Res 2006, 66: 1028I-10286.

33. Masri S, Lui K, Phung S, Ye J, Zhou D, Wang X, Chen S: Characterization of the weak estrogen receptor alpha agonistic activity of exemestane. Breast Cancer Res Treat 2009, I 1 6:46 I-470.
34. Wang $X$, Masri S, Phung S, Chen S: The role of amphiregulin in exemestane-resistant breast cancer cells: evidence of an autocrine loop. Cancer Res 2008, 68:2259-2265.

35. Marquez-Garbon DC, Chen HW, Goodglick L, Fishbein MC, Pietras $\mathrm{RJ}$ : Targeting aromatase and estrogen signaling in human non-small cell lung cancer. Ann N Y Acad Sci 2009, I I 55: 194-205.

36. Koutras A, Kritikou I, Giannopoulou E, Dimitropoulos K, Kalofonos $\mathrm{H}$ : Dual inhibition of aromatase and epidermal growth factor receptor in non-small cell lung cancer [abstract]. J Clin Oncol 2009, 27:e22189.

37. Waterman $H$, Yarden $Y$ : Molecular mechanisms underlying endocytosis and sorting of ErbB receptor tyrosine kinases. FEBS Lett 2001, 490:142-152.

38. Lin SY, Makino K, Xia W, Matin A, Wen Y, Kwong KY, Bourguignon L, Hung MC: Nuclear localization of EGF receptor and its potential new role as a transcription factor. Nat Cell Biol 200 I, 3:802-808.

39. Yue X, Song W, Zhang W, Chen L, Xi Z, Xin Z, Jiang X: Mitochondrially localized EGFR is subjected to autophagic regulation and implicated in cell survival. Autophagy 2008, 4:64I-649.

40. Altiok N, Koyuturk M, Altiok S: JNK pathway regulates estradiol-induced apoptosis in hormone-dependent human breast cancer cells. Breast Cancer Res Treat 2007, 105:247-254

4I. Grivas PD, Antonacopoulou A, Tzelepi V, Sotiropoulou-Bonikou G, Kefalopoulou Z, Papavassiliou AG, Kalofonos H: HER-3 in colorectal tumourigenesis: From mRNA levels through protein status to clinicopathologic relationships. Eur J Cancer 2007, 43:2602-26II.

42. Giannopoulou E, Antonacopoulou A, Floratou K, Papavassiliou A, Kalofonos H: Dual targeting of EGFR and HER-2 in colon cancer cell lines. Cancer Chemother Pharmacol 2009, 63:973-98I.

43. Kuwada SK, Scaife CL, Kuang J, Li X, Wong RF, Florell SR, Coffey RJ $J r$, Gray PD: Effects of trastuzumab on epidermal growth factor receptor-dependent and -independent human colon cancer cells. Int J Cancer 2004, 109:291-30I.
Publish with BioMed Central and every scientist can read your work free of charge

"BioMed Central will be the most significant development for disseminating the results of biomedical research in our lifetime."

Sir Paul Nurse, Cancer Research UK

Your research papers will be:

- available free of charge to the entire biomedical community

- peer reviewed and published immediately upon acceptance

- cited in PubMed and archived on PubMed Central

- yours - you keep the copyright

Submit your manuscript here:

http://www.biomedcentral.com/info/publishing_adv.asp
BioMedcentral 